\title{
Power in Global Value Chains
}

Dallas, Mark P.; Ponte, Stefano; Sturgeon, Timothy J.

\section{Document Version}

Accepted author manuscript

Published in:

Review of International Political Economy

DOI:

10.1080/09692290.2019.1608284

Publication date:

2019

License

Unspecified

Citation for published version (APA):

Dallas, M. P., Ponte, S., \& Sturgeon, T. J. (2019). Power in Global Value Chains. Review of International Political Economy, 26(4), 666-694. https://doi.org/10.1080/09692290.2019.1608284

Link to publication in CBS Research Portal

\section{General rights}

Copyright and moral rights for the publications made accessible in the public portal are retained by the authors and/or other copyright owners and it is a condition of accessing publications that users recognise and abide by the legal requirements associated with these rights.

Take down policy

If you believe that this document breaches copyright please contact us (research.lib@cbs.dk) providing details, and we will remove access to the work immediately and investigate your claim. 


\section{Power in Global Value Chains \\ Mark P. Dallas, Stefano Ponte, and Timothy J. Sturgeon}

Journal article (Accepted manuscript*)

\section{Please cite this article as:}

GDallas, M. P., Ponte, S., \& Sturgeon, T. J. (2019). Power in Global Value Chains. Review of International Political Economy, 2614), 666-694. https://doi.org/10.1080/09692290.2019.1608284

This is an Accepted Manuscript of an article published by Taylor \& Francis in Review of International Political Economy on 23 Jul २०19, available online:

DOl: http://www.tandfonline.com/10.1080/09692290.2019.1608284

* This version of the article has been accepted for publication and undergone full peer review but has not been through the copyediting, typesetting, pagination and proofreading process, which may lead to differences between this version and the publisher's final version AKA Version of Record.

Uploaded to CBS Research Portal: July २०२० 


\title{
Power in Global Value Chains
}

\author{
ABSTRACT \\ Power has been a foundational concept in global value chain (GVC) research. Yet, in most \\ GVC scholarship, power is not explicitly defined and is applied as a unitary concept, rather than \\ as having multiple dimensions. Clarifying the concept of power has become particularly urgent in \\ recent years given the proliferation of new GVC frameworks, which extend beyond dyads of \\ transacting firms or firm-state linkages by incorporating other stakeholders and mechanisms - \\ including NGOs, labour unions, standards and conventions. In this paper we propose a typology \\ for the varied meanings and usages of power in GVCs. We delineate two principal dimensions of \\ power in GVCs: transmission mechanisms - direct and diffuse; and arena of actors - dyads and \\ collectives. Combined, these two dimensions yield four ideal types of power: bargaining, \\ demonstrative, institutional and constitutive. We offer brief illustrations of these four types of \\ power and provide an agenda for further research in the field.
}

\section{KEYWORDS:}

Global value chains (GVC), power, governance. 


\section{Introduction}

Power has been a foundational concept in examining global value chains and production networks (hereafter, GVCs). However, over time, its usage and meaning - both implicit and explicit - have become overstretched. In foundational GVC research (e.g. Gereffi, Humphrey and Sturgeon, 2005), for example, the concept of power focuses on the uneven bargaining relationships between transacting firms. In the broader theoretical literature on power this would be thought of as 'coercive' power, in which one actor utilizes incentives or sanctions directly to compel another actor to act according to their wishes (e.g. Dahl, 1956). As such, coercive power has the characteristics of being intentional, conflict-oriented and resource-centred. The insights gained from this view of power are not trivial. For instance, the cross-border projection of buyer power through supply chains overlays, entwines with, and sometimes truncates the power of nation-state-centered actors, causing the experiences of recent developers to become 'compressed' (Whittaker, Sturgeon, Okita and Zhu, forthcoming).

However, as the analytic lens of GVCs has expanded, conceptualizations of power have implicitly proliferated, expanding from dyads to collectives and from formal to informal. For instance, firms and non-firm actors gradually and collectively come to mutual accommodation over explicit and formal industrial standards and certifications, as well as over informal conventions and best practices (Nadvi, 2008; Ponte and Gibbon, 2005). Likewise, consumer and social movements shape GVCs, and vary in their degree of formal organization (Bair and Palpacuer, 2015). In other instances, power can be transmitted across GVCs in more 'diffuse' ways, such as through the demonstration effect of highly visible agents or by network effects. Likewise, while some socioeconomic structures are overtly cooperative or contentious, power can 
also be hidden from view and acquire a background taken-for-grantedness, which when fully consolidated both embody and fix power relationships. This happens when the very preferences, interests and worldviews of GVC actors are moulded in ways that systematically advantage some over others, such as in the social construction of notions of quality (Bush, 2011; Quark, 2013).

Thus, following Dallas (2014), we argue that GVC research would benefit from a widening of its conceptual and empirical lens on power to better understand collective and emergent outcomes which may derive from social action that is only weakly intentional or even nonintentional. Or, as Hayek describes it, social order derived 'by human action, but not by human design.' Such ideas can help propel GVC research beyond the exercise of power by clearly defined 'lead firms' and state-level actors.

Despite widespread references to 'power' in GVC research, the concept is rarely explicitly defined, has not been systematically analysed, and is most often applied as a unitary concept rather than having multiple dimensions. To begin to address these deficiencies, we offer a systematic framework that draws from the varied implicit usages of power in GVC and GVC-adjacent literatures. In doing so, the framework draws from broader social theories on power. However, it does so selectively, both because not all forms of power are equally relevant to GVC analysis and because the concept of power itself is essentially contested, with long-standing disputes over its meanings that we cannot hope to settle here.

The goal of this paper is to develop a framework that clarifies how different types of power can explain the dynamics of governance in GVCs. We define GVC governance as the actions and norms that shape the conditions for inclusion, exclusion and mode of participation in a value chain, which in turn determine the terms and location of value addition and capture. To broaden the lens for examining GVC governance, we conceptualize four types of power, and highlight how they 
can combine and layer together in complex ways across inter-firm linkages, within specific nodes, and as they influence governance up and down the chain or across the whole chain (Ponte and Sturgeon 2014).

Empirical GVC research has focused heavily on inter-firm governance, which corresponds with just one of our four types of power in our framework - bargaining power. Bargaining power has long been central to the industrial organization and market structure literatures (Chamberlin 1933; Williamson 1975), as well as to Schumpeterian barriers to entry created by firm-level capabilities that are difficult, time-consuming, or impossible for competitors to replicate (Penrose 1959; Teece, Pisano and Shuen, 1997). Undeniably, these ideas have been extensively utilized in GVC-related theory building (Gereffi et al., 2005; Sturgeon 2002, 2009; Ponte and Sturgeon 2014).

That said, we seek to broaden the analytical lens beyond inter-firm bargaining and show that bargaining power itself does not simply arise endogenously from inter-firm transacting alone. Rather, it is also shaped by combinations of distinct types of power and from a diverse array of actors both within and outside a given bargaining dyad, node, or GVC. Overall, the expanding field of GVC research necessitates a conceptual framework that incorporates its implicit and explicit usages. The end result of our exercise is a typology of power in GVCs, based on two dimensions: 'transmission mechanisms' and 'arena of actors'. We distinguish between transmission mechanisms that are 'direct' and 'diffuse,' and arena of actors that are 'dyads' and 'collectives.' Combining these two dimensions yields a four-category typology that incorporates many of the types of power observed in GVCs: bargaining, demonstrative, institutional and constitutive.

In the rest of this article, we first discuss how the concept of power has broadened over time in the GVC and cognate literatures, and link some of these uses to broader theories of power. Next, 
we delineate the two principal dimensions of our typology of power in GVCs, and describe the four types of power that emerge from it. Finally, we apply our typology to three brief empirical case studies in wine, apparel and mobile telecomm GVCs to illustrate how our four types of power provide insights into the shaping of governance in specific GVCs. We conclude by reflecting on the methodological implications of examining power through different lenses and provide an agenda for further research and theory-building.

\section{Power and GVC Governance}

While the concept of power has been central to GVC analysis since its inception, its meanings have gradually proliferated. Broadly speaking, power in GVC research has expanded beyond the agent-centered, direct and coercive forms of power evident in governance as 'driving' and 'linking,' to forms of power in which agents are less defined and power is more diffuse, as demonstrated in governance as 'normalizing' (Gibbon, Bair and Ponte, 2008). As illustrated below, although firms remain central to all GVC research, the number and type of actors has expanded, exposing new avenues for the exercise of power in GVCs. This section first traces the role of power through a history of the GVC field, and then briefly connects GVC literatures to broader social theories of power.

\subsection{A History of Power in Global Value Chains}

Hopkins and Wallerstein (1986: 159) defined a Global Commodity Chain (GCC) as 'a network of labour and production processes whose end result is a finished commodity.' Their key innovation was examining individual global industries through the lens of interlinked labour and

production processes that create an international division of labour. Although firms were not 
acknowledged as important agents, over time states became increasingly prominent actors in shaping GCCs by altering the terms of trade as goods and investment crossed borders.

By contrast, in Gereffi's $(1994,1999)$ seminal work, power in GCCs was linked to the ability of lead firms to 'drive' the organization of international production networks. Gereffi's key contribution was to highlight the role of 'global buyers' (e.g., retailers and branded merchandisers) in 'driving' the export-led development of certain East Asian economies from the 1950s through the 1980s. In East Asia, 'high-capacity' states (Evans, 1995) worked in tandem with business elites to upgrade the position of their domestic companies in global industries, and this dovetailed with the strategies of retailers and branded merchandisers, especially in the United States but also in Europe, to source lower cost consumer goods to feed the 'retail revolution' at home (Feenstra and Hamilton 2006). This set off a co-evolutionary dynamic between buyer and supplier strategies that Kimura (2007: 97-98) refers to as 'dynamic external fit.'

In this context, GVC participation offered developing country firms access to knowledge, markets and other valuable competitive assets (Taglioni and Winkler, 2016). However, these advantages were often bounded (especially the move into own brand production) and thus contingent on the terms of inclusion and exclusion imposed by lead firms (Gibbon and Ponte, 2005; Humphrey and Schmitz 2002). In sum, firms were pivotal agents in Gereffi's approach, as global buyers exercised control over their own supply chains and developing country suppliers sought to upgrade within GCCs, often backed by developmental industrial policies.

Although Gereffi's earlier work did not specify the sources of power in buyer-driven or producer-driven chains, Sturgeon (2009) suggested technological intensity as the main differentiator. In producer-driven chains, lead firms set up foreign affiliates to undertake production because manufacturing tended to represent a difficult-to-replicate set of competencies 
and intellectual property assets that rendered outsourcing unwise. However, rampant outsourcing and offshoring during the 1990s and 2000s meant that formerly producer-driven industries were taking on some of the characteristics of buyer-driven chains, and this signalled a need for a dynamic theory rather than a static typology. The result was a GVC governance theory focused on three key conditions (transactional complexity, codifiability of information and supplier capability) that structured how lead firms linked to suppliers (Gereffi et al., 2005; Humphrey and Schmitz, 2002; Sturgeon, 2002). Coercion remained the primary power dynamic between firms, given that asymmetries are required for lead firms to engage in the 'explicit coordination' of the chain that differentiated GVCs from arms-length trade. This shifted the conception of lead firm power from an unspecified notion of 'driving' to an analysis of dyadic inter-firm 'linking' (Gibbon et al., 2008). Inter-firm power was further conceptualized as varying by degrees from very high, in the 'hierarchies' between MNC subsidiaries and headquarters, to very low in pure arms-length 'markets,' with buyer-supplier linkages that were 'captive,' 'relational' and 'modular' falling in between (Gereffi et al., 2005).

In GVC governance theory, power mainly resides in the lead firm. But the rise of global suppliers and platform leaders such as Intel in formerly producer-driven chains led some to speculate whether a new era of supplier-led value chains was dawning (Borrus and Zysman, 1997). However, with a few exceptions, the ability of lead firms to determine the functional division of labour along a GVC through buyer power continues as the central hypothesis and empirical result of much firm- and industry-level GVC research. The ability of lead firms to choose and switch between suppliers allows them to demand additional services and ever-lower real unit prices.

After the mid-2000s, several new approaches to power in GVC emerged. One approach, 'governance as normalizing,' concerned the process of re-aligning a given practice to be 
compatible with a standard or norm (see Gibbon et al., 2008), which includes important elements of self-regulation and in some cases, the shaping of actor preferences. This work drew on convention theory (Ponte, 2009; Ponte and Gibbon, 2005), governmentality (Gibbon and Ponte, 2008; Ouma, 2015; Raj-Reichert, 2013) and neo-Gramscian approaches (Bair and Palpacuer, 2015; Levy, 2008). Other research has shown how GVC governance can be shaped, not only by the strategic choices of lead firms and powerful suppliers, but also by standards and certifications on quality and sustainability, multi-stakeholder initiatives, corporate social responsibility and social movements. Some of this work focused on the compromises and pedagogies of 'quality' and has sought to explain that the shaping of ideas, measurement devices, and operationalization of quality shape power relations (Nadvi, 2008; Quark, 2013). While this work highlights how control over the qualification of specific products can be a key source of power for lead firms, it also reveals how counter-actions by other value chain actors can sometimes challenge the status quo.

Another set of contributions has highlighted processes of disarticulation and counter-action in GVC governance, which de-emphasize the linkage bias of GVC analysis by focusing on suppliers exiting GVCs in specific situations, the processes of suppliers clawing back power from lead firms, and the growing role of actors not directly involved in production (Bair and Werner, 2011; Bair, Berndt, Boeckler and Werner, 2013). This work shows that less powerful actors are sometimes able to disarticulate and disentangle from uneven and exploitative GVCs relations, or to simply refuse to participate in GVCs (see also Berndt and Boeckler, 2011; Goger, 2013; Havice and Campling 2013).

Over time, the conception of power in GVCs has thus broadened from a focus on 'buyer power' to include how key suppliers in some industries have been able to establish more powerful 
positions by following paths and strategies that not only create value but also retain it (Kaplinsky, 2005; Kawakami, 2011; Sako and Zylberberg, 2017; Sturgeon, 2002, 2009). This leads away from unipolarity, where power is concentrated in one functional position in the value chain, towards multipolarity, where power might appear in various functional positions (Fold, 2002; Ponte and Sturgeon, 2014). Multipolarity can also involve actors outside the value chain, such as international NGOs, trade unions, governments, and multi-stakeholder initiatives (Nadvi and RajReichert, 2015).

A cognate literature on Global Production Networks (GPNs) focuses on more complex configurations of economic activity than the intentionally parsimonious ones used in GVC governance theory. In doing so, it highlights the variety of non-firm actors in shaping the organization of economic activity (Coe, Dicken and Hess, 2008; Coe and Yeung, 2015; Henderson, Dicken, Hess, Coe and Yeung, 2002; Hess and Yeung, 2006). In an effort to break down power into different forms, Henderson et al., 2002 proposed a tripartite distinction between corporate, institutional (largely state-led), and collective (non-firm, non-state) power. This framework placed primary emphasis on different types of actors, but focused only on direct forms of power between clearly defined actors. ${ }^{1}$ In more recent work, GPN scholars have proposed a structural-cumrelational approach to power (Coe and Yeung, 2015: 65). They argue that a structural approach to power in a network should not only be based on a firm's position within the network (i.e., network

${ }^{1}$ Henderson et al. (2002) differentiate state and non-state actors into distinct categories (institutional and collective, respectively). By contrast, in our framework, all groups of actors are categorized as 'collectives,' but they are not necessarily fully incorporated into a well-defined organization, such as loosely-organized social movements, or when ideas, best practices and conventions diffuse among actors. 
centrality), but also through the strength of association (network density); and that structural positions do not automatically lead to pre-ordained outcomes as power is exercised in contingent and contextual ways. Actors thus 'draw upon different forms of power in order to take on an advantageous position in GPNs that favour their value creation, retention, and capture' (Coe and Yeung, 2015: 66-67).

\subsection{Parallels between Social Theories of Power and GVCs}

While the GVC literature includes useful treatments of power that are worth incorporating into a systematic typology of power in GVC governance, we enrich our framework by selectively drawing on relevant concepts from broader social theories of power. Although the concept of power is contested and lacks a single, recognized meaning, the longstanding four 'faces' of power - coercion, agenda-setting, preference-shaping, and social construction - provide some useful distinctions for understanding GVC governance, which we summarize very briefly here. ${ }^{2}$

Coercive power: The first face of power is quite similar to GVC research focused on governance as 'driving' and 'linking,' as well as GPN literature in which power is primarily coercive. It is exercised by well-defined actors with the resources to engage in intentional action to achieve clearly defined outcomes, in which overt behaviour is the observable manifestation of power. These ideas are well represented by Coe and Yeung (2015: 66), who offer one of the few explicit definitions of power in the GVC and GVC-adjacent literature: 'the capacity of an actor to

${ }^{2}$ The citations refer only to the initial article which first proposed a new face of power, but of course, each was followed by extensive debate and reformulations, which we cannot elaborate given space constraints. For more on each, see Clegg (1989). 
exercise and achieve control over a particular strategic outcome in its own interests.' This broadly parallels classic definitions of coercive power, such as Robert Dahl's (1956: 202-3) in which: '[Actor] A has power over B to the extent that he can get B to do something that B would not otherwise do.' Conflict between actors is central to coercive power, starting with Weber's (1947) classic 'carrying out of one's will despite resistance.' Again, Coe and Yeung explicitly highlight the conflict-orientation of much GVC literature as 'the ability of one actor to affect the behaviour of another actor in a manner contrary to the second actor's interests, [and] can also reflect the ability of one actor to resist an unwanted imposition by another actor' (2015: 17, emphasis added).

Agenda-setting power: The second face of power (Bachrach and Baratz, 1962) does not radically diverge from the first, except that it rejects the idea that power is present only when there is overt, observable conflict in the course of decision-making. Instead, the second face suggests that power is also exerted when actors successfully remove contentious issues from the realm of decision-making, referred to as 'agenda-setting' power. Thus, power also exists when decisions are not being made, such as when institutions and organizations are mobilized to consistently tilt the playing field in ways that eliminate areas of conflict. Although not identical to agenda-setting power, industrial standard-setting and the influence of state institutions in GVCs sometimes can play this role. This happens not so much during the process of standardsetting or institution-building, which can be conflict-ridden and coercive for those who lose out or must accept the results, but rather once standards and institutions have become fully established, as for example when documentation, review, and certification services become standard practices. In the digital economy, platforms can play a similar role. The outcome of established standards is often to remove issues as legitimate items of contention, thus narrowing the field of overt conflict. 
Preference-shaping: In the third face (Lukes, 2005), the powerful are able to dominate the less powerful by shaping their preferences to conform to the interests of the powerful. This becomes especially insidious when the less powerful are unconscious of their domination, and when this is not intentionally engineered by the powerful, perhaps because history has hidden the roots of preference-shaping domination. The expansion of the GVC literature into governance as 'normalizing' comes closest to the third face of power, compared to other types of governance. However, the distinction between preference-shaping and influencing action (behaviours) has not been clearly identified in GVCs, though as discussed below, hints of it are evident.

Social construction: The fourth face of power (Digeser, 1992) is expressed through processes of socialization, through routines and practices by which people are disciplined to behave in normalized ways. While preference-shaping still is central, there are no longer clearly defined powerful actors who actively aim to transform preferences or benefit from preferenceshaping. While our actions contribute to shaping other subjects, our own subjectivity is also constructed through disciplinary routines and practices, such that '[individuals] are always in the position of simultaneously undergoing and exercising this power' (Foucault 1980: 98). This face of power is least common in GVCs, although some research has broadly drawn from these ideas (e.g. Gibbon and Ponte, 2008).

In sum, while coercive power is certainly common and important in understanding GVC dynamics, broader social theories of power signal the need for a more expansive understanding of power, including power that is more 'diffuse.' In the discussion of the faces of power, the range is from the agent-centred first and second faces to the more diffuse third and fourth faces - where beliefs, preferences and worldviews of the actors are shaped less directly. Similarly, following Dallas (2014), we consider both agent-centred and non-agential power, and include self-organizing 
collectives that emerge as the unintended outcome of the aggregate actions of unrelated actors. In such expressions of power, membership boundaries are permeable and thus hard to conceptualize as specific actors intentionally pursuing well-defined outcomes. Rather than circumscribing the concept of power, we adopt a moderately expansive scope in which the locus of power need not always inhere within specific power-wielding actors, need not always be exerted with full intentionality, and need not be exhibited in overt inter-actor conflicts. We also consider forms of diffuse power that become embedded in knowledge and shape preferences and interest, perhaps in ways unknown to key actors. In the next section, we draw from these ideas selectively to construct an analytical framework on power in GVCs.

\section{The Dimensions and Types of Power in GVCs}

In this section we develop a framework to specify the various dimensions of power as relevant for the analysis of GVCs. We begin by differentiating the two main dimensions of our typology of power: 'transmission mechanisms' and 'arena of actors.' Transmission mechanisms specify how power is transmitted, intentionally or not, between actors. The arena of actors specifies the configuration of actors among which power is transmitted, divided into dyads and collectives. The two dimensions yield a typology that includes four modes of power (see Figure 1) - bargaining, demonstrative, institutional and constitutive.

\section{Figure 1: A typology of power in global value chains (GVCs)}

[Figure 1 here] 


\subsection{Two Dimensions of Power in GVCs: Transmission Mechanisms and Arena of Actors}

\section{The Transmission of Power: From Direct to Diffuse}

GVC and related literatures differentiate (at least implicitly) different kinds of power by highlighting whether the transmission is more direct (Coe and Yeung, 2015; Gereffi, 1994; Gereffi et al., 2005) or more diffuse (Dallas, 2014; Gibbon and Ponte, 2005). While an explicit framing of the direct/diffuse distinction is still lacking in the GVC literature, it has been made in other typologies of power (e.g. Barnett and Duvall, 2005; Mann, 2012). Mann differentiates 'authoritative' and 'diffused' power, with the former 'involv[ing] commands by an individual or collective actor and conscious obedience by subordinates' and the latter as 'spread[ing] in a relatively spontaneous, unconscious and decentered way. People are constrained to act in definite ways, but not by command' (2012: 6).

While this distinction is well-known, differences remain over whether actors only exert power when they intentionally seek to fulfil goals that serve their interests. Mann is clear that his four sources of power (military, political, economic, ideological) are all exercised in intentional ways: 'these [sources of power] are organizational means by which we can efficiently attain our varied goals, whatever these may be' (ibid.). By contrast, Barnett and Duvall (2005: 44) incorporate many types of unintended behaviors and outcomes into the concept of 'diffuse' power to provide 'a systematic way of thinking about power in terms of both agency and structure'. Our framework 
falls into the latter category, with diffuse power including lesser degrees of intentionality (see Dallas, 2014). ${ }^{3}$

In direct forms of transmission, the actor (or collective) wielding power and those who are objects of it are relatively easy to identify by all parties. The exertion of direct power is most often intentional and the goals of powerful actors well-known. Direct power also generally inheres within actors or collectives (including the state) in the sense that they possess resources or other means to leverage their structural or network position within GVCs. ${ }^{4}$ The utilization of these resources by influential actors are more likely to be explicit and precise, in the sense that exercising control includes specific, measurable and monitorable requirements. These attributes of direct power are often mutually self-reinforcing. For instance, because the actors are clearly defined, act intentionally in relation to each other and are in possession of well-defined resources to exert power, the exercise of power tends to be more transparent, precise, and usually includes monitoring the behaviour of actors over whom influence is exerted. As elaborated in the next section, examples of the direct exertion of power in GVCs include the relative bargaining power between

${ }^{3}$ Although our transmission dimension is similar to Barnett and Duvall (2005), our second dimension (arena of actors as dyadic or collective) is quite specific to GVC research. Furthermore, our three empirical examples at the end of this paper urge researchers to weave and layer the four types of power together, while Barnett and Duvall's framework appears as a menu of discrete choices.

${ }^{4}$ The notion of possession of power is controversial. We agree with Allen (2003) that possession of resources and exercise of power should be differentiated, but we are not opposed to the idea that some forms of power can be 'possessed' by an actor. In fact, an actor in possession of resources can exert power without even utilizing its resources, e.g. when other actors change their behavior in anticipation of the reaction of the powerful. However, we are also not arguing that all forms of power are possessed by actors (see below on diffuse transmissions of power). 
two transacting firms, lead firm-specific protocols for suppliers, specifications for use of technology platforms, government regulations, rules set by business associations for its members, and environmental protection standards set by third-parties.

Power transmission can also be diffuse, as when actors follow broad societal trends and transmission is through demonstration or network effects or through emergent 'best practices' (e.g. corporate codes of conduct) and dominant quality conventions. Furthermore, when norms are 'naturalized' they can take on a taken-for-granted status, which Lukes (2005: 28) describes as 'the supreme and most insidious exercise of power' because it embeds power into the worldview of actors, disabling the prospects for resistance. Power can also be diffuse when individual actors or collectives fail to realize the many unintended consequences of their actions, even when these consequences are relevant to their interests. The actions of powerful agents and collectives may have an influential demonstration effect on other actors, leading the latter to inadvertently change their behaviour in ways that are beneficial to incumbents. Power can also be diffuse when groups of actors behave in a manner akin to loosely-organized social movements. Diffuse transmission is most often a function of gradual evolutionary changes which slowly become normalized and embedded into the routines, practices and beliefs of actors. In the GVC literature, such dynamics can be present in the creation and diffusion (or demise) of standards, conventions, best practices, and in collective band-wagoning during the pre-paradigmatic stages of technological diffusion. In these circumstances, actors wield little direct power on their own, but when substantial numbers of actors alter their behaviour in rapid succession, they exert power through diffuse mechanisms, even though they may not belong to a formal organization or participate in a common network.

Diffuse transmissions of power are much harder to observe empirically, motivating Lukes $(2005,1)$ to suggest that 'power is at its most effective, when it is least observable.' As such, there 
is an inherent bias against (and undersupply of) this sort of empirical research. This is partly because the set of actors, resources, goals and intentions are not always clearly identifiable, even by the principals themselves, making unambiguous instances of diffuse power more rare in research. $^{5}$

Nevertheless, diffuse power is implicit in various theories of social change, such as 'emergence' (Feenstra and Hamilton, 2006; Miller and Page, 2009), where a collective and emergent social order is not projected outward from a single, identifiable locus of power, but arises from the behavioural regularities of actors that may be unintentional or weakly intentional (Dallas, 2014). In some cases, agents may individually participate or defect in succession, perhaps through observations of the behaviour of peers. This can create a chain of isomorphic reactions and lead to sudden changes in the dynamics of power. In these circumstances, power cannot always be said to be 'possessed' by any particular actor. Rather, the transmission of power is diffuse and continues to be so as long as large numbers of actors behave in relative uniformity (Hayward and Lukes, 2008). Unlike detailed contracts or protocols, the exertion of diffuse power is not necessarily explicit, precise, or easy to monitor or enforce - especially when collective action flows from loosely organized groups or is driven by social norms.

Diffuse power arising from social movements and collectives of actors, and the emergence of conventions in GVCs have been well documented (e.g. Bair and Palpacuer, 2015; Gibbon and Ponte, 2005), but less recognizable instances of diffuse power in GVCs can come with the sudden arrival of an enabling technology. While the agents introducing a new technology are usually easily recognizable, the process by which technology is deployed is not necessarily controlled by

\footnotetext{
${ }^{5}$ See Gaventa (1980) for a well-known attempt to reveal Lukes' third face of power.
} 
first-movers. Rather, the adoption of technology can operate through a social movement-like dynamics - in which a certain threshold of (unorganized) defectors of a prior technology is required before a new technology becomes diffused, or when an institutional or adjacent set of technological capabilities gradually emerges to overcome any "liability of newness' for young firms in an industry (Stinchcombe, 1965; Freeman et al, 1983), or when platforms propagate markets through network effects (Parker, Van Alstyne and Choudary, 2016).

In sum, although direct and diffuse transmission are not always crisply dichotomous, they can be differentiated through several dimensions, including: (1) how clearly the actors can identify each other; (2) the degree of intentionality and goal-orientation in their actions; (3) whether or not the locus of power resides within clearly defined actors (perhaps through exclusive possession of resources); and (4) the relative clarity and effectiveness of assessment and sanction regimes. Since diffuse power is harder to detect, one purpose of our framework is to provide researchers with the tools to observe it in GVCs.

\section{The Arena of Actors: From Dyads to Collectives}

A second dimension in our typology of power in GVCs is the 'arena of actors.' An 'arena' is the full population of interacting actors or collectives in a specific GVC. For the sake of simplicity, we propose two broad categories of actor arenas - dyads and collectives. Both will be present in all GVCs, and our assumption is that research might benefit from analysing them separately. The dyadic arena is a common focus in the GVC literature, as it is in related literatures such as theories of the firm and strategic management. A dyad is the arena studied in Gereffi's (1994) research on 'lead' firms and their links to suppliers or 'intermediaries,' and is even more explicitly the focus in Gereffi et al.'s (2005) theory of GVC governance, where power asymmetry decreases as one 
moves from hierarchy toward market linkages. This is because power exerted between the dyadic pair is shaped by relative bargaining positions rooted in purchasing power and competence power (Sturgeon, 2009).

The second arena of actors, less explicitly researched and theorized in the GVC literature, involves collectives of actors. The locus of power in this case is a function of the collective behaviours of multiple players acting simultaneously, intentionally or not. We avoid using the term 'institutions' here because some collectives are more diffuse and lack institutional or formal organizational traits. ${ }^{6}$ Nevertheless, some collective arenas are institutionalized and examples include business associations, multi-stakeholder initiatives, and state administrative units. In an institutionalized collective, there is a focal organization, such as a government agency, that sets more or less transparent rules for all, or for specific groups of actors (e.g. in industrial policy) who experience the rules and their consequences along with others. Any bargaining by actors takes place in the context of the collective (e.g. through an industry association or pressure group). This is what distinguishes power dynamics in collectives from that operating through dyadic interactions.

While a collective might appear to be a unitary actor with coherent rules, leadership or organization, it might also be more loosely coordinated. Thus some collectives of actors will lack a single or clear organization, codified rules, and a sense of leadership - e.g. social movements, and looser networks that are not built around a central organization. Here, the boundaries of those

\footnotetext{
${ }^{6}$ For this reason, we reserve the term 'institutional power' for cases where the collective arena is combined with direct power transmission (one of our four combinations in Figure 1).
} 
'included' and 'excluded' in the arena are not always precisely knowable, perhaps even for the actors themselves.

\subsection{Four Types of Power in GVCs}

Combining the two types of transmission mechanisms and the two arenas of actors explained in the previous section yields four ideal types of power in GVCs, as shown in Figure 1: bargaining, institutional, demonstrative and constitutive. It is worth noting that the four types of power are not mutually exclusive and typically coexist -- mixing, layering and combining in complex ways over time. For GVC actors, this can happen when one type of power is derived or dependent upon another type, such as when the (dyadic) bargaining power of one firm over another derives from its positional power in a collective, or when a supplier uses its dyadic competence power to encapsulate valuable assets formerly held by a collective (e.g. offers a proprietary version of open source software). One type of power can also transform into another type, for instance when vaguely defined best practices are codified as a de facto standard - representing a shift from diffuse to more direct power within collectives (a type of agenda-setting power). These will differ across cases, but we believe that differentiating types of power is an important first step to carry out evolutionary analyses of how different transmission mechanisms and arenas of actors overlap and evolve over time. In fact, a critical advantage of differentiating types of power in GVCs is the possibility of sketching how a dyadic bargaining relationship may actually embed other forms of power. What some research may identify as straightforward coercive power within a dyadic relation may actually be the result of pre-existing processes of social construction which at the present time appear taken-for-granted - e.g. the journey, involving many actors, from ill-defined 
best practices to precise standards, or the history of how specific concepts of supply management became dominant (Gibbon and Ponte, 2008).

It can be quite challenging to comprehensively map out power relations in a given GVC. For instance, if power is exerted within an arena by a loose collective it does not mean that within a particular organization or among members of the collective, power is somehow absent. Both arenas may interact. An organization may appear to exercise power as a unitary actor in one arena, while its internal divisions actually affect its external behaviour. Thus, power relationships are almost always layered and nested at different levels of analysis; yet, they are most easily studied as distinct arenas - each benefitting from its own analysis of power. How deep one goes in examining such multi-level articulations depends on the nature of one's research questions, design and focus.

\section{Bargaining Power - Dyadic and Direct}

Bargaining power in GVCs most frequently refers to power in firm-to-firm relations, and is the most common form of power found in GVC and related literatures. This is partly because of the literature's original focus on linkages between 'lead' firms in advanced economies and suppliers in developing countries (Gereffi, 1994; Gereffi et al., 2005). In GVC governance theory, there is some variability in the arena of actors: unitary (internal to the firm) in the hierarchical form; strongly dyadic in the captive form; less so in the relational form, and weakening rapidly across the modular and market forms where the codification of the inter-firm linkage both enables and necessitates suppliers serving multiple lead firms (Gereffi et al., 2005). The number of possible partners also affects the level of power asymmetry predicted by GVC governance theory (from high in hierarchy to low in markets). Still, the arena of actors is populated largely by firms, and 
the analysis of power is based on an aggregation of firm-to-firm (dyadic) bargaining snapshots. As attention shifted to various forms of supplier power, the dyadic relationship has remained central to the analysis, such that supplier power is mainly judged in relation to lead firms.

However, bargaining power can be founded upon other forms of power, with which it becomes layered and combined. This means that even though bargaining power is exerted directly between dyads of firms, power that is external to the dyad often helps to structure the particular linkage (see our empirical examples below). For instance, even though 'modular' is a description of a type of dyadic linkage, this form of power often derives from collective diffusion processes — such as when many firms adopt a particular standard, provide complementary assets, or sell products or services over platforms (Gawer and Cusumano, 2002). Thus, modularity can be thought of as simultaneously operating across dyadic and collective arenas (Dallas, 2014).

\section{Demonstrative Power - Dyadic and Diffuse}

Demonstrative power operates through informal transmission mechanisms along value chains between buyers and suppliers, or aspiring value chain actors. For instance, successful upgrading by a specific supplier may induce imitation in other supplier tiers or among competitors. Unlike bargaining power in which lead firms explicitly coordinate the activities of suppliers, demonstrative power can come into play when, for example, lead firm actions do not intend to elicit upgrading but suppliers do so to position themselves for inclusion in a specific GVC. As illustrated in the empirical examples below, demonstration power can also be exerted by non-firm actors. Furthermore, activities in one GVC node can also have demonstration effects up and down the chain (Ponte and Sturgeon 2014), or even in adjacent industries. 
Demonstrative power can also gradually evolve into constitutive power. The exercise of demonstrative power, for example, remains dyadic only as long as the 'model' - the entity exerting demonstrative power - has individualized effects on other actors, even if it happens across multiple dyads. This might occur when firms or other organizations make strategic decisions based upon observation or mimicry of another actor's behavior. However, if over time many actors begin to form mutually acknowledged understandings of 'best practices' or 'appropriate' social action, then dyads can transform into collectives and the seeds of constitutive power can be planted, perhaps in the form of community- or industry-wide norms (see below).

While this form of power is acknowledged in the GVC literature, there has been little effort to assess these adaptations and demonstration effects which often occur among 'excluded' GVC actors - an implicit criticism arising from the disarticulation literature (Bair and Werner, 2011). More research is needed to explain dynamics external (but nevertheless contiguous) to dyadic GVC activities, so that dynamic choices faced by suppliers and other less powerful firms in GVCs can be better understood (Sako and Zylberberg, 2017).

\section{Institutional Power - Collective and Direct}

Institutional power is a form of direct power that is exercised by collectives with some level of formal organization such as business associations, multi-stakeholder initiatives, technological platforms, or administrative units of the state. While power in dyadic relationships stems from resources controlled by singular organizations, such as internally created technological or organizational know-how or financial and other material resources, in collective arenas it is at least partly external in the sense of being dependent upon the strategic actions of groups of actors who collectively set rules through a formal organization. 
The state, when regulating the conduct of all actors or categories of actors, wields institutional power; but, multi-stakeholder initiatives can also exercise institutional power, even when they provide voluntary tools for business conduct or the social and environmental conditions of production. When such initiatives end up being codified in third-party certifications, they can indirectly shape dyadic relationships, as when buyers require certifications from suppliers to meet specific requirements. Thus, non-firm actors can be important governing actors in GVCs.

Unlike dyadic arenas in which clearly identified actors exert power over other actors, in collective arenas power can derive from disarticulated actions of multiple actors. There is typically substantial contention within any collective action, and conflicts may involve numerous dyadic relationships. Moreover, within collectives such as standard-setting bodies, powerful actors jockey for the inclusion of terms that are especially favourable to them - witness the struggle among powerful telecom firms to get their proprietary technologies included in de facto standards.

A less intuitive form of institutional power is derived through the network effects of technological platforms. Network effects increase the value of a product or service as more firms or consumers acquire or use it. This is the strategic motivation for 'platform ownership,' in which the focal firm provides clear methods for others to connect to its technology and incentivizes other firms to provide complimentary products or services. Many of today's most powerful and valuable technology companies, such as Microsoft, Facebook, Google, Amazon and Alibaba, derive their power through platform ownership. While this type of power remains reliant on the continued participation of its user base and complementors, thereby making power partially external to the focal firm, platform owners also accrue immense power if they provide services that users feel are indispensable (Gawer and Cusumano, 2002). 
What distinguishes institutional power from bargaining power is that it derives from the combined actions of actors that share a clear membership in an initiative or organization, adopt a particular standard, or link to a common platform. As the degree of formal institutionalization diminishes, 'institutional' power (collective and direct) becomes 'constitutive' power (collective and diffuse).

\section{Constitutive Power - Collective and Diffuse}

Constitutive power is manifested when collective arenas do not exhibit clear or formal common membership. Power is not embodied in particular actors or institutions and the exercise and outcomes of power may be entirely unintended. Constitutive power emerges when broad-based collective action involves minimal formal institutionalization or an unclear or emergent common identity or purpose. Constitutive power is at most weakly codified and lacks direct forms of enforcement. In some circumstances actors may be aware that a general norm or convention has been violated and sanctions may be collectively imposed, but when enforcement is decentralized it is often subtle and nuanced compared to the pre-ordained arbiters and judges that normally enforce institutional power. In some circumstances constitutive power may be built into the takenfor-granted worldviews of actors and unconsciously shape their preferences. For instance, when conventions concerning how to define 'quality' remain uncontested, they simply retreat into the background as the 'normal' business environment.

Additional examples of constitutive power include the slow diffusion of outsourcing or financialization as general 'best practices' against which firms come to progressively structure themselves (Gibbon and Ponte, 2005), the loose social movement-like diffusion of sustainability 
concerns in the governance of GVCs (Ponte, 2019), or the normative role slowly generated through social movements on corporate conduct and transparency (Bair and Palpacuer, 2015).

Over time, constitutive power can become increasingly formalized and codified and thus evolve into institutional power. Conversely, institutional power can be challenged, de-legitimized and de-codified, or practices and norms might become so taken-for-granted that the need for institutional development and enforcement fades. The main difference between institutional and constitutive power is that in institutional power the transmission is direct, while in constitutive power it is diffuse. Many norms, broad conventions and best practices exist in this non-formalized state, less overtly exercised and even hidden from self-conscious view.

\section{Empirical Examples}

In this section, we briefly apply our typology to three empirical examples and include stylized graphic representations of the actors, arenas of actors, power transmission mechanisms, and actor constellations for each case. Figure 2 provides a basis for the case-specific diagrams that follow. It includes symbols for three types of firm-level actors: lead firms, suppliers and third-party developers, and lead firms with more than one line of business. A few additional actors are specified, including states, organizations (such as non-governmental organizations and industry associations), and individuals. Collectives are represented by circles that can accommodate any number of actors. Direct power transmission is represented by solid lines, while diffuse power transmission is represented by dotted lines. In both cases, thicker lines indicate a higher degree of power asymmetry. 
Figure 2. Power in GVCs: actors, arenas, transmission mechanisms \& actor constellations

[Figure 2 here]

These simple, highly stylized diagrams are by no means meant to represent an exhaustive set of actor constellations. Social movements can involve any type of actor and sometimes evolve to develop more structure, including centralized organizations with selective membership. Multistakeholder initiatives can also involve a range of actors, and exhibit both direct (institutional) and diffuse (constitutive) power relationships among actors. Most importantly, for the three empirical examples that follow, firms, industries, organizations, technology platforms, and social movements both change over time and usually involve a co-evolving set of actors and actor constellations.

Our first example explores the power configurations at play in the wine GVC. This case lays out the complex dynamics of power emerging from how the conceptions and operationalization of quality changed in the industry. Our second example is presented in narrative format on the institutionalization of labour standards in apparel. Here, we follow the development of labour standards from the initial formation of social movements to a set of formalized multi-stakeholder initiatives. Our third example compares mobile phones with different operating systems to highlight different types of 'platform-based' collectives. In all three examples, we specifically consider how actors outside the GVC intercede upon firm-level actors.

\subsection{Power in wine GVCs}


The analysis of power in wine GVCs (Figure 3) highlights the importance of power beyond dyadic bargaining and traditional top-down institutional processes. Of course, buyer-supplier bargaining is still important in areas such as product specifications, product portfolios and logistics. Traditionally, depending on the quality segment, bargaining power was concentrated in buyers' hands in lower-end markets, while producers could exercise more power in higher-end markets. However, with an increasing proportion of wine now sold through retailers carrying a wide portfolio of quality, rather than through specialist shops, bargaining power is being consolidated in buyers' hands (Ponte, 2009).

Demonstrative power in the wine GVC was traditionally shaped by élite wine producers in some of the top regions of the 'Old World' (France, Italy, Spain, Portugal). This was both reinforced and challenged by individual journalists and professional tasters through their reviews. However, through the gradual ideational creation of the 'new wine consumer' (see below under constitutive power), demonstrative power has been revolutionized and now is increasingly transmitted by wine tasters/scorers (e.g. Robert Parker), marketers, 'flying winemakers,' viticulturists and marketers (Itçaina, Roger and Smith, 2016). These actors increasingly shape the 'new' wine styles and aesthetic preferences that then move from one producer to the next through isomorphic but uncoordinated diffuse transmission. In other words, a movement from producerdriven to demand-driven demonstration effects has taken place - which itself consolidates the shift of bargaining power towards large-scale and diversified wine buyers.

While institutional power in the wine GVCs is most clearly exercised by the public sector through local, national and regional regulation, multi-stakeholder initiatives also play an important role, such as fair trade, organic and biodynamic certification bodies, industry associations and wine exhibitions, fairs and competitions (Ponte 2009). Regulatory interventions have been historically 
stronger in Old World countries; however, pressure to adapt regulation to the demands of the "new consumer' (see below) and to recover market share from New World (non-European) wines has led to major regulatory adjustments in Old World countries, especially following the 2008 European Union wine market reform. This included a simplification of categories for geographic indication wines, permission to sell 'table wines' under a brand name, the possibility to indicate grape varietal, and the abandonment of the main forms of 'production' support (Itçaina et al., 2016). Most of these reforms have moved institutional power away from producers and their associations and towards buyers: marketers, merchants and retailers.

\section{Figure 3. Illustration of power dynamics in wine GVCs}

[Figure 3 here]

Constitutive power in the wine GVC emanates from more subtle manifestations of power, such as the ideational creation of the 'new wine consumer,' which was gradually developed by marketing experts, biochemists and economists in 'New World' producing countries and facilitated by the growing sales of wine in supermarkets. These efforts were collective but not in ways that suggest explicitly organized action. Over time, the new consumer became a wellconstructed group, understood as demanding more standardized and predictable wines year after year, something that less regulated New World wine producers are better equipped to deliver (Itçaina et al., 2016). Other examples of constitutive power included changes in broadly accepted preferences for wine styles or varietals (e.g. towards 'Parker reds', fully bodied wines with deep colours and high alcohol levels), in understandings of novelty and tradition (e.g. a broader 
acceptance of viticultural and winemaking practices that were not traditionally allowed within certain indications geographic origin) and in acceptable forms of packaging and labelling (e.g. increased acceptance of screwcaps) (Ponte, 2009). These changes were slow, evolutionary and weakly- or even un-coordinated. Nevertheless, they had the unintended effect of reinforcing the power of merchants and retailers at the expense of producers (especially small-scale ones), and the power of New World value chain actors at the expense of Old World actors - although the latter have resisted these changes.

\subsection{Power in apparel GVCs}

In apparel, we narrate the interaction of different forms of power over time in the creation of multi-stakeholder initiatives (MSIs) like the Fair Labour Association and Worker Rights Consortium in the United States, which generate and diffuse labour standards (Figure 4). Thus, the narrative begins outside GVCs and ends within them. While these two MSIs ultimately coalesced into formal institutions, they originally evolved from a complex amalgam of constitutive, demonstrative and institutional forms of power.

Before their formalization into MSIs, global labour standards were promoted through consciousness-raising about sweatshop conditions among loosely connected communities of NGOs, including consumer groups, religious organizations, universities and student groups, human rights groups and labour unions. In social movement-like fashion, these loose amalgams of organizations sought to transform ethically-produced apparel from a niche product for the few, into the presumed norm for all consumers. Over time, this requires an incremental but fundamental shift in the values of consumers and executives of major buyer firms, which, if consolidated, would 
become a form of constitutive power. Unlike with the emergence of the 'new wine consumers,' these groups were more self-conscious in pursuing explicit goals, but their actions were largely uncoordinated, illustrating variability in constitutive power

Demonstrative power played a role in the increasing institutionalization of these loose alliances. For instance, both the pre-MSI NGOs and the stakeholders creating the MSIs regularly utilized the International Labour Organization's (ILO) long-standing 'Declaration on the Principles and Rights of Workers' and its evolving core labour standards when orienting their organizational missions, internal standards, monitoring and other organizational characteristics. This is best characterized as demonstrative power because each organization individually adapted ILO standards as their 'model' and adapted them to their own individual goals. On the other hand, the ILO can be seen as melding demonstrative with more formal institutional power since it diffused best practices through training sessions, information, and discussion forums, all within a framework of a formal international organization composed of member states.

However, institutional power is also exerted within the ILO when powerful business groups have successfully utilized agenda-setting power to prevent the ILO from promulgating labour rights for freedom of association and collective bargaining - resistance that some sought to reverse after Bangladesh's Rana Plaza fires in 2013. The ILO illustrates our earlier point of power exercised at several levels of analysis, in this case agenda-setting internal to the organization and demonstration effects outward from an organization.

The transformation from constitutive to institutional MSI power really began after sequential media revelations in the mid-1990s of child labour and sweatshop conditions in foreign factories supplying firms like Nike, The Gap, and Kathy Lee Gifford's private label (Mandle, 2000). Jolted by the media coverage and under pressure by civil society groups, the Clinton administration 
established a taskforce in 1996 which brought global apparel companies and a collection of leading NGOs together into a loose organization called the Apparel Industry Partnership (AIP). Although the AIP collapsed when key unions and NGOs withdrew their support, the multi-stakeholder talks continued for three years, after which a fully institutionalized multi-stakeholder NGO called the Fair Labour Association (FLA) was formed. A splinter group, the Worker Rights Consortium (WRC), was also formed by universities and student groups for collegiate apparel, but with less corporate participation.

\section{Figure 4. Illustration of power dynamics in multi-stakeholder initiatives for labor standards in apparel GVCs}

[Figure 4 here]

Through this process, the institutional power held by various US government agencies played key roles by providing momentum, credibility and media attention. However, the government also used more coercive forms of power, such as the threat of government regulation of global buyers to get them to the bargaining table, and later the US State Department and USAID provided grants to establish the FLA and develop its programs (MacDonald, 2011).

Arguably, it is through the institutionalized power of MSIs like the FLA and WRC that the broader movement exerts influence in inter-firm bargaining power in ways not previously possible through more diffuse kinds of power. Global buyers who become members leverage their bargaining power to insist that their suppliers undergo FLA audits and remediation. Likewise, suppliers can become members of the FLA to gain advantage over competitors. Either way, when 
suppliers upgrade by complying with labour standards, dyadic governance with buyers is more likely to shift from market-based linkages to deeper relational linkages, especially as MSIs have shifted from straightforward compliance monitoring to supplier capacity-building, providing technical assistance, 'root cause analysis,' joint problem solving and diffusion of best practices. Nevertheless, whether the withdrawal of MSI certification has an effect still depends in part on the reactions of supporting civil society groups and other stakeholders, so MSI institutional power still remains partly reliant on constitutive power, illustrating the interactive and combinatory layering of different kinds of power.

\subsection{Power in mobile telecomm GVCs}

The development of the mobile phone industry has rapidly evolved from the traditional inter-firm bargaining power of the 'feature phone' era to become overlain with platform-based institutional power in the 'smart phone' era. Beginning in the 1990s, a mass market in feature phones arose as handsets became smaller and more portable, prices fell, and network infrastructure expanded. Bargaining power was mainly concentrated in a set of incumbent lead handset firms with a long presence in the telecommunications industry, most prominently Nokia, Motorola, Ericsson, and Siemens (Sturgeon and Linden, 2011).

While high levels of modularity in product design and supply chains meant that handset firms could source a variety of core and generic components from external suppliers, integrative systemlevel design of each model phone was carried out internally by handset makers. Thus, their bargaining power remained central, based on their difficult-to-replicate, system-level competencies and scale in component purchasing. However, as the number of features escalated, 
integrating them became an increasingly laborious and expensive process, raising the risks associated with failure (Thun and Sturgeon, 2017).

Institutional power became central to mobile phones with the rise of the smartphone, which are built as a series of nested platforms. This can be dated to January 2007 when Apple introduced the iPhone, a new type of keypad-less handset based on a mobile version of Apple's PC operating system called iOS (Figure 5). Like Mac and Windows-based PCs, the iPhone was set up as a platform to run a suite of Apple-supplied and third-party applications available on-line through Apple's 'App Store.' Platform owners such as Apple exert institutional power because they create broadly accepted standards and interfaces to which third-parties must adhere (e.g. Apple's application programming interface). The powerful network effects created by successful platforms create a rich ecosystem of third-party contributors, and each additional participant enriches the product for all - and by extension the institutional power of the platform owner.

Figure 5. Illustration of power dynamics in mobile handset GVCs: Apple iOS vs. Linuxbased Google Android

[Figure 5 here]

However, the institutional power of platforms has also been established through constitutive power, as evidenced by Google's Android operating system which closely followed Apple's iOS in 2008. A key difference is that Google based its proprietary platform on open-source software distributions developed through a highly-diffuse community of programmers with no intention of assisting with Google's proprietary system. While handsets running Android have features similar 
to the iPhone, including an ecosystem of third-party app developers centred on the GooglePlay store, Google provided Android to handset makers for free to drive mobile users to its search engine to capture advertising revenue. Since the Android OS encapsulated many of the integrative functions previously carried out by handset makers, incumbent firms found their core system integration competencies (and bargaining power) cannibalized and were pushed out of the market by a bevy of low-cost competitors offering Android-compatible phones. Low prices drove sales (but not profits) that far surpassed the iPhone; Android smartphones captured 80\% market share by 2013 .

Importantly, Android is a proprietary ‘distribution' version of the Linux open source operating system. Linux and related code is freely available online through the Linux Foundation, and has a large community of software developers who voluntarily make improvements, offer new Linux distributions for specific applications, and provide informal online technical support for engineers using Linux software (Bretthauer, 2001). This is best described as constitutive power because the voluntary, non-proprietary and anti-corporate ethic that binds the Linux community originally evolved through software engineers who sought to undermine the near-monopoly bargaining power held by Microsoft on PC operating systems.

However, companies such as Red Hat, Canonical, and SUSE, have since developed for-profit business models by selling proprietary and tailored distributions of Linux, and by providing support for large companies using Linux to use in their products. Like Android, these create adjacent platform ecosystems which support a host of third-party developers. In Figure 5, these appear under constitutive power because the platforms are founded on the Linux kernel and remain deeply linked with the on-going developments in the Linux open source community. Nevertheless, they mainly function as proprietary, closed platforms because they have clearly defined and 
monitored boundaries and rules for participation by third parties, and thus are depicted as migrating into the arena of institutional power. Finally, the rise of platform ecosystems in general serve as a model with demonstrative power, which spurs competitive mimicry through the creation of new downstream platform-based mobile ecosystems such as Uber, AirBnB, and WeChat (Parker et al., 2017; Sturgeon, 2017).

\section{Conclusion}

Recently, the GVC literature has expanded to include a multitude of new actors, socialeconomic processes and theoretical approaches. This has stretched the conceptual lens of power beyond the confines of firms and purely materialist and strategic notions of power. However, this conceptual stretch has not been accompanied by a broader analytic framework on power, which usually remains a unitary and undefined concept lurking in the background of GVC research. Power tends to be both everywhere and nowhere in GVC literature, and while this usefully encourages the proliferation of varied and overlapping meanings, the time seems ripe to develop an organizing framework.

After examining the various ways in which power has been conceptualized and applied in GVC literatures, this article offers a typology which incorporates the varied meanings of power. The typology has two dimensions: the arena of actors (dyads and collectives) and the transmission of power (direct and diffuse). This yields four main forms of power: bargaining (dyadic and direct), demonstrative (dyadic and diffuse), institutional (collective and direct) and constitutive (collective and diffuse). The typology provides a framework to explicitly map the varied actors, their interactions and most importantly, the types of power exerted on and in a value chain, as visualized 
through stylized diagrams like Figures 2 through 5. However, several challenges remain to be addressed in future work.

First, explicit mappings of power can be quite challenging in practice and the types of power exerted across a value chain are not always easily distinguishable in empirical settings. For instance, the identification of the 'arena of actors' may appear to be a straightforward exercise. However, this is not necessarily the case, as illustrated previously in the case of demonstrative power which can gradually bleed into constitutive power as dyadic demonstration effects become widespread and mutually acknowledged, imperceptibly giving rise to collective understandings of best practices or norms. Similarly, categories in the typology are not mutually exclusive. For instance, we suggest that struggles between seemingly unitary organizations in one arena can be simultaneously reflected in struggles within an organization, such as in state bureaucracies, or divisions within corporations. To assist researchers, we highlight four attributes that help to differentiate direct and diffuse transmission: 1) the degree to which actors are clearly identifiable, 2) the extent of intentionality in their actions, 3) the degree to which power resides in specified actors, and 4) the relative clarity of the tools, measurement regimes and methods of exerting power. Still, there can be ambiguity since these attributes are also not always clearly dichotomous.

Second, power is 'combinatory,' in that different types of power are expressed together, with one type often overlapping or undergirding another. Bargaining power is usually powerfully conditioned by the other three forms of power, as illustrated in the wine and apparel examples. This implies that bargaining power is rarely endogenous to the dyadic transactions, and thus a full accounting requires empirical investigation of other types of power that undergird it. Thus, power in GVCs is most usefully mapped with multiple layers. 
Third, the arena of actors and transmission of power typically evolve over time - such as when Google drew on the Linux community to create a proprietary and institutionalized mobile phone OS platform, or the evolution of the sweatshop movement from loosely confederated organizations into formalized MSIs. The issue of time raises a host of unaddressed questions about the conditions under which power shifts between our four ideal-types. When are certain types of power likely to undergird others in value chains, or reinforce each other in re-combinations of power? Are some combinations of power more resistant to change and thus best considered structural constraints on GVC actors? For instance, network effects often generate monopoly power through path-dependent lock-in. While winner-take-all situations are easy to identify after the fact, predicting when and why network effects arise or when they might unravel is far more difficult. Despite these challenges, differentiating the dimensions and distinct types of power and how they intermix in particular situations and over time could lead GVC researchers to a deeper understanding of how GVCs are governed. 


\section{References}

Allen, J. (2003). Lost geographies of power. Malden, MA: Blackwell.

Bachrach, P. and Baratz, M.S. (1962). Two faces of power. American Political Science Review, 56(4), 947-52.

Bair, J. and Palpacuer, F. (2015). CSR beyond the corporation: Contested governance in global value chains. Global Networks 15, S1-S19.

Bair, J. and Werner, M. (2011). Commodity chains and the uneven geographies of global capitalism: A disarticulations perspective. Environment and Planning A, 43, 988-997.

Bair, J., C. Berndt, M. Boeckler and M. Werner. (2013). Dis/articulating producers, markets, and regions: New directions in critical studies of commodity chains. Environment and Planning A, 45 (11), 2544-2552.

Barnett, M. and Duvall, R. (2005). Power in international politics. International Organization, 59(1), 39-75.

Berndt, C. and M. Boeckler. (2011). Performative regional (dis) integration: Transnational markets, mobile commodities, and bordered North-South differences. Environment and Planning A, 43 (5), 1057-1078.

Borrus, M. and Zysman, J. (1997) Wintelism and the changing terms of global competition: Prototype of the future? Working Paper 96B, Berkeley Roundtable the International Economy. 
Bretthauer, D. (2001). Open source software: A history, published works, 7. University of Connecticut. Available at http://digitalcommons.uconn.edu/libr_pubs/7

Chamberlin, E. (1933). The theory of monopolistic competition. Cambridge: Harvard University Press.

Clegg, S.R. (1989). Frameworks of power. London: Sage Publications.

Coe, N., Dicken, P. and Hess, M. (2008). Global production networks: Realizing the potential. Journal of Economic Geography, 8, 271-295.

Coe, N.M. and Yeung, H.W. (2015). Global production networks: Theorizing economic development in an interconnected world. Oxford: Oxford University Press.

Dahl, R.A. (1957). The concept of power. Behavioral Science, 2(3), 201-215.

Dallas, M. (2014). Cloth without a weaver: Power, emergence and institutions across global value chains. Economy and Society, 43(3), 315-345.

Digeser, P. (1992). The fourth face of power. The Journal of Politics, 54(4), 977-1007.

Evans, P. (1995). Embedded autonomy: States and industrial transformation. Princeton, N.J.: Princeton University Press.

Feenstra, R. and Hamilton, G. (2006). Emergent economies, divergent paths: Economic organization and international trade in South Korea and Taiwan. Cambridge: Cambridge University Press. 
Fold, N. (2002). Lead firms and competition in 'bi-polar' commodity chains: Grinders and branders in the global cocoa-chocolate industry. Journal of Agrarian Change, 2(2), 22847.

Foucault, Michel (1980). Two Lectures. In Colin Gordon (ed.) Power/Knowledge: Selected interviews and other writings, 1972-1977. New York: Pantheon.

Freeman, John; Carroll , Glenn, and Hannan, Michael. 1983. "The Liability of Newness: Age Dependence in Organizational Death Rates." American Sociological Review, 48(5): 692710

Gaventa, J. (1980). Power and powerlessness: Quiescence and rebellion in an Appalachian valley. Oxford: Clarendon Press.

Gawer, A. and Cusumano, M. (2002) Platform leadership: How Intel, Microsoft and Cisco drive industry innovation. Cambridge, MA: Harvard Business School Press.

Gereffi, G. (1994). The organization of buyer-driven global commodity chains: How US retailers shape overseas production networks. In G. Gereffi and M. Korzeniewicz (eds.) Commodity chains and global capitalism, (pp. 95-133). Westport: Greenwood Press.

Gereffi, G. (1999). International trade and industrial upgrading in the apparel commodity chain. Journal of International Economics 48(1), 37-70.

Gereffi, G., Humphrey, J. and Sturgeon, T. (2005). The governance of global value chains. Review of International Political Economy, 12(1), 78-104.

Gibbon, P. and Ponte, S. (2005) Trading down: Africa, value chains and the global economy. Philadelphia: Temple University Press. 
Gibbon, P. and Ponte, S. (2008). Global value chains: From governance to governmentality? Economy and Society, 37(3), 365-392.

Gibbon, P., Bair, J. and Ponte, S. (2008). Governing global value chains: An introduction. Economy and Society, 37(3), 315-338.

Goger, A. (2013). From disposable to empowered: Rearticulating labor in Sri Lankan apparel factories. Environment and Planning A, 45 (11), 2628-2645.

Havice, E. and Campling, L. (2013). Articulating upgrading: Island developing states and canned tuna production. Environment and Planning A, 45 (11), 2610-2627.

Hayward, C., and Lukes, S. (2008). Nobody to shoot? Power, structure, and agency: A dialogue. Journal of Power, 1(1), 5-20.

Henderson J., Dicken, P., Hess, M., Coe, N. and Yeung, H.W-C. (2002). Global production networks and the analysis of economic development. Review of International Political Economy, 9(3), 436-464.

Hess, M. and Yeung H. W-C. (2006). Whither global production networks in economic geography? Past, present and future. Environment and Planning A, 38, 1193-1204.

Hopkins, T. and Wallerstein, I. (1986) Commodity chains in the world economy prior to 1800. Review X (1) 157-170.

Humphrey, J. and Schmitz, H. (2002). How does insertion in global value chains affect upgrading in industrial clusters? Regional studies, 36(9), 1017-1027.

Itçaina, X., Roger, A. and Smith, A. (2016). Varietals of capitalism: A political economy of the changing wine industry. Ithaca, NY: Cornell University Press. 
Kaplinsky, R. (2005). Globalization, Poverty and Inequality. London: Polity.

Kawakami, M. (2011). Inter-chain dynamics in notebook PC value chains and the rise of Taiwanese original design manufacturing firms. In M. Kawakami and T. Sturgeon (eds.) The Dynamics of Local Learning in Global Value Chains: Experiences from East Asia, (pp.16-42). Basingstoke, UK: Palgrave Macmillan.

Levy, D. (2008). Political contestations in global production networks. Academy of Management Review, 33(4), 943-963.

Lukes, S. (2005). Power: A radical view (2nd ed.). New York: Palgrave Macmillan.

MacDonald, K. (2011). The Fair Labor Association. In D. Held and T. Hale (eds.), Handbook of Transnational Governance Innovation, (pp.243-251). Cambridge: Polity Press.

Mann, M. (2012). The sources of social power: Global empires and revolution, 1890-1945 (Vol. 3). Cambridge: Cambridge University Press.

Miller, J. and Page, S. (2009). Complex adaptive systems: An introduction to computational models of social life. Princeton: Princeton University Press.

Nadvi, K. (2008). Global standards, global governance and the organization of global value chains. Journal of Economic Geography, 8(3), 323-343.

Nadvi, K. and Raj-Reichert, G. (2015). Governing health and safety at lower tiers of the computer industry global value chain. Regulation \& Governance, 9(3), 243-258.

Ouma, S. (2015). Assembling export markets: The making and unmaking of global food connections in West Africa. Oxford: Wiley-Blackwell. 
Parker, G., Van Alstyne, M. and Choudary, S. (2016). Platform revolution: How networked markets are transforming the economy - And how to make them work for you. New York: W. W. Norton \& Company.

Penrose, E. (1959). The theory of the growth of the firm. Oxford: Basil Blackwell.

Ponte, S. (2009). Governing through quality: Conventions and supply relations in the value chain for South African wine. Sociologia Ruralis 39(3), 236-257.

Ponte, S. (2019). Green Capital, Brown Environments: Business, Power and Sustainability in a World of Global Value Chains. London: Zed Books.

Ponte, S. and Gibbon, P. (2005). Quality standards, conventions and the governance of global value chains,' Economy and Society, 34(1), 1- 31.

Ponte, S. and Sturgeon, T. (2014). Explaining governance in global value chains: A modular theory building effort. Review of International Political Economy, 21(1), 195-223.

Quark, A.A. (2013). Global rivalries: Standards wars and the transnational cotton trade. Chicago: University of Chicago Press.

Raj-Reichert, G. (2013). Safeguarding labour in distant factories: Health and safety governance in an electronics global production network. Geoforum, 44, 23-31.

Sako, M., and Zylberberg, E. (2017). Supplier strategy in global value chains: shaping governance and profiting from upgrading. Socio-Economic Review.

Stinchcombe, Arthur L. 1965. "Social structures and organizations.” In: J. G. March (ed.) Handbook of Organizations, pp. 142-193. Chicago: Rand McNally. 
Sturgeon, T. (2002). Modular production networks: A new American model of industrial organization. Industrial and Corporate Change, 11(3), 451-496.

Sturgeon, T. (2009). From commodity chains to value chains: Interdisciplinary theory building in an age of globalization. In J. Bair (ed.) Frontiers of Commodity Chain Research, (pp.110135). Stanford: Stanford University Press.

Sturgeon, T. and Linden, G. (2011). Learning and earning in global value chains: Lessons in supplier upgrading in East Asia. In M. Kawakami and T. Sturgeon (eds), The dynamics of local learning in global value chains: Experiences from East Asia, (pp.207-226).

Basingstoke, UK: Palgrave Macmillan.

Sturgeon, Timothy. (2017). The 'new' digital economy and development. UNCTAD Technical Note on IT for Development (ICT4D) No. 8. Web access: http://unctad.org/en/PublicationsLibrary/tn_unctad_ict4d08_en.pdf

Taglioni, D., and Winkler, D. (2016). Making global value chains work for development. Washington: World Bank.

Teece, D. J., Pisano, G., and Shuen, A. (1997). Dynamic capabilities and strategic management. Strategic Management Journal, 18(7), 509-533.

Thun, E. and Sturgeon, T. (2017). When global technology meets local standards: Reassessing China's mobile telecom policy in the age of platform innovation. MIT Industrial Performance Center Working Paper 17-001.

Weber, M. (1947). The theory of social and economic organization. New York: Free Press. 
Whittaker, D.H., Sturgeon, T., Okita, T. and Zhu, T., Forthcoming. Compressed development. Oxford: Oxford University Press.

Williamson, O. (1975). Markets and Hierarchies. New York: The Free Press. 
Figure 2: A typology of power in global value chains (GVCs)

\begin{tabular}{|c|c|c|}
\hline & \multicolumn{2}{|c|}{ Transmission Mechanisms } \\
\hline & Direct & Diffuse \\
\hline $\begin{array}{l}\text { Arena } \\
\text { of } \\
\text { Actors }\end{array}$ & $\begin{array}{l}\text { Bargaining Power } \\
\text { - Operates in firm to firm } \\
\text { relations } \\
\text { - Can exhibit different degrees of } \\
\text { asymmetry in hierarchy, captive, } \\
\text { relational, modular, and market } \\
\text { linkages } \\
\text { - Can also operate when powerful } \\
\text { firms interact individually with } \\
\text { government agencies to carve } \\
\text { out exceptions to rules, etc. } \\
\\
\text { Institutional Power } \\
\text { - Operates through government } \\
\text { regulation, multi-stakeholder } \\
\text { initiatives and/or other } \\
\text { institutionalized forms } \\
\text { Can leverage and be leveraged } \\
\text { through industrial standards and } \\
\text { codified 'best practices' } \\
\text { - Can be "agenda-setting" by } \\
\text { removing issues from the } \\
\text { bargaining table, as well as de } \\
\text { facto and de jure standards to } \\
\text { support platforms and their } \\
\text { ecosystems }\end{array}$ & $\begin{array}{l}\text { Demonstrative Power } \\
\text { - Operates through informal } \\
\text { 'transmission' mechanisms along } \\
\text { value chains between buyers and } \\
\text { suppliers, or aspiring value chain } \\
\text { actors. } \\
\text { - Can be shaped by quality } \\
\text { conventions implicitly accepted by } \\
\text { parties to a dyadic transaction } \\
\text { - Can drive isomorphism among or } \\
\text { between lead firms and suppliers, or } \\
\text { among non-firm actors } \\
\text { Constitutive Power } \\
\text { - } \\
\text { Operates through broadly accepted } \\
\text { norms, expectations and best } \\
\text { practices, e.g., isomorphism at the } \\
\text { industry or societal levels. } \\
\text { Can arise through decentralized } \\
\text { collaboration among loosely or un- } \\
\text { affiliated actors, sometimes } \\
\text { engendering new norms and } \\
\text { practices (e.g. non-proprietary, } \\
\text { collaborative open source software). }\end{array}$ \\
\hline
\end{tabular}

Note: Examples are illustrative, not comprehensive. 
Figure 2. Power in GVCs: actors, arenas, transmission mechanisms, \& actor constellations

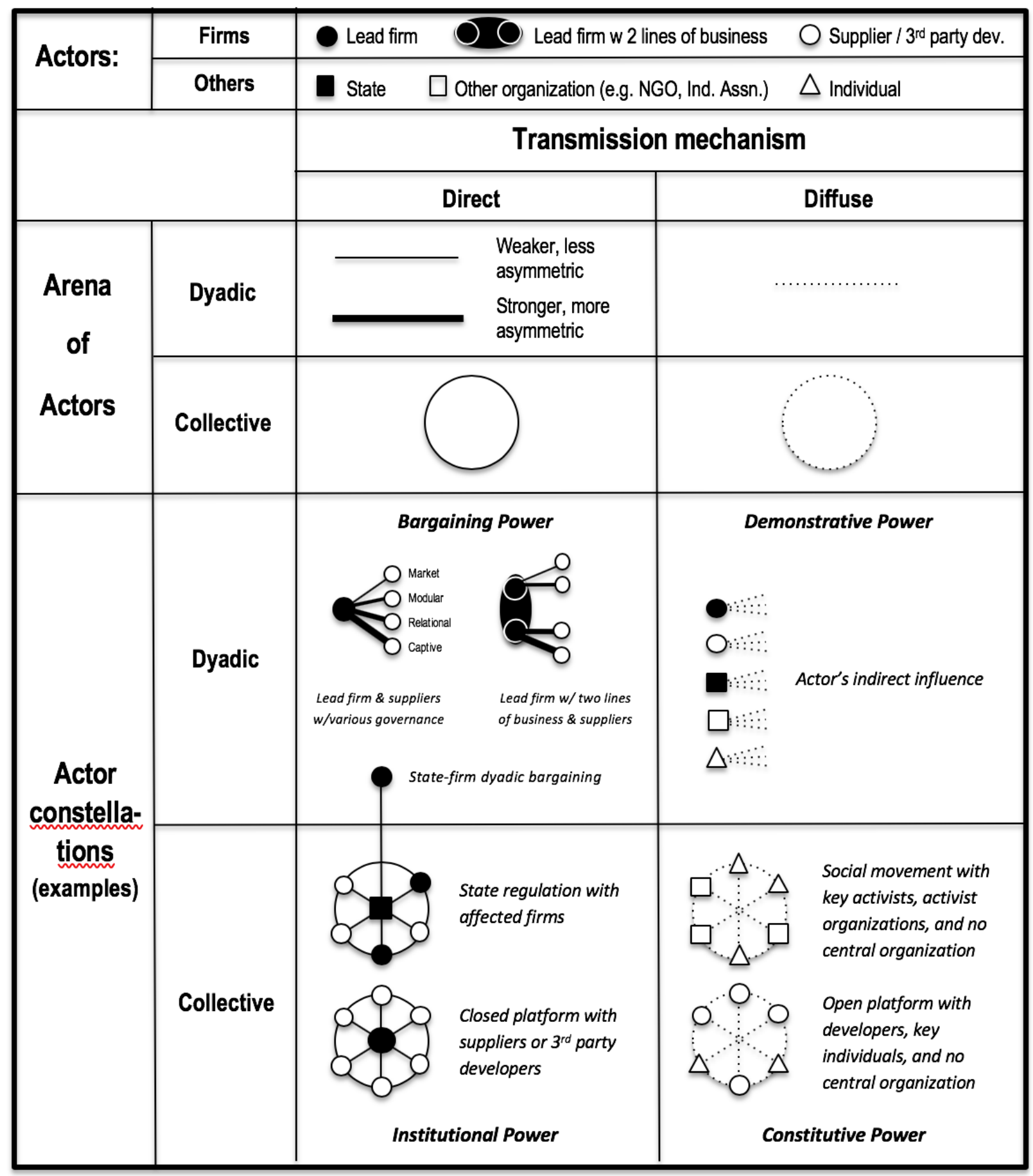


Figure 3. Illustration of power dynamics in wine GVCs

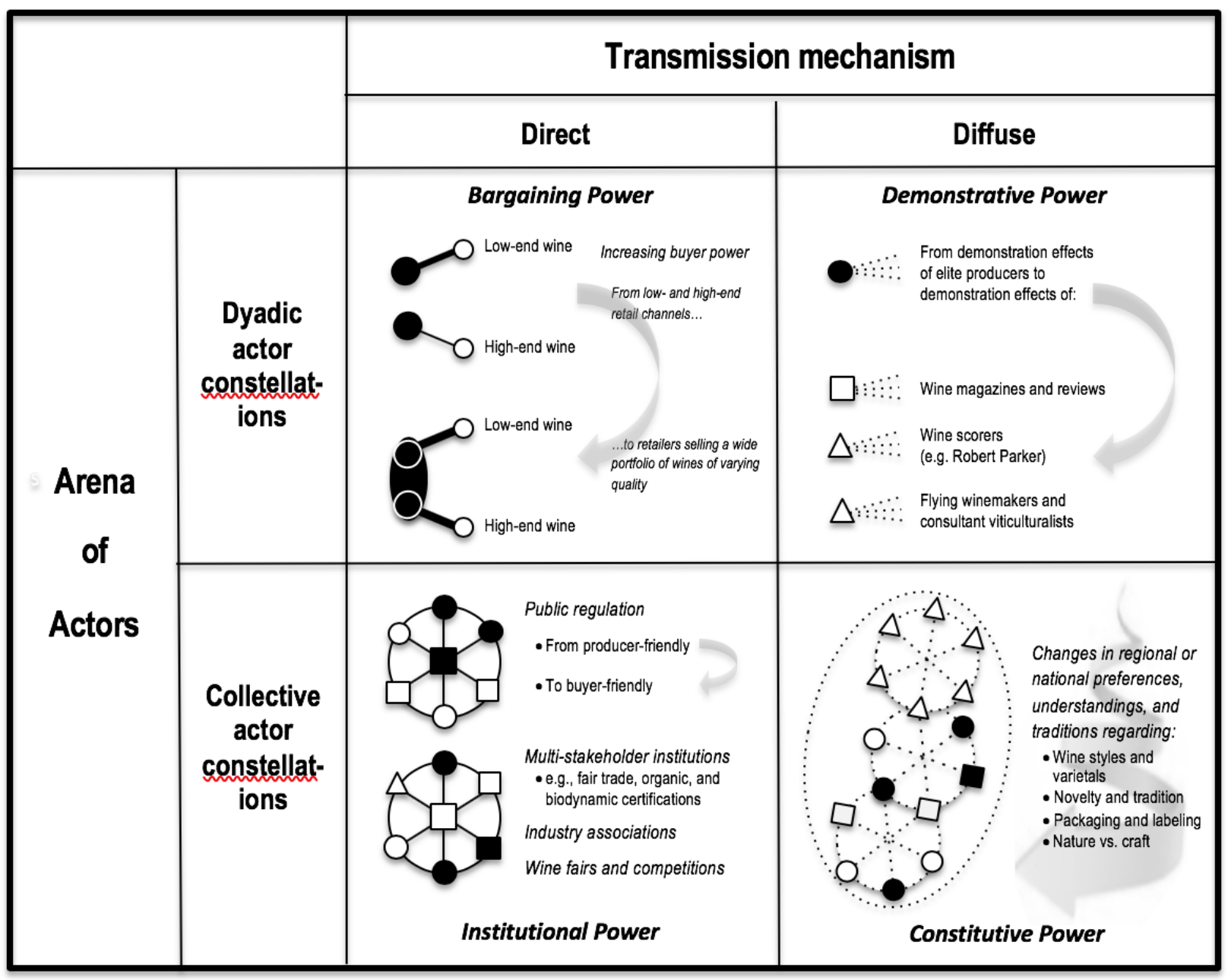


Figure 4. Illustration of power dynamics in multi-stakeholder initiatives for labor standards in apparel GVCs

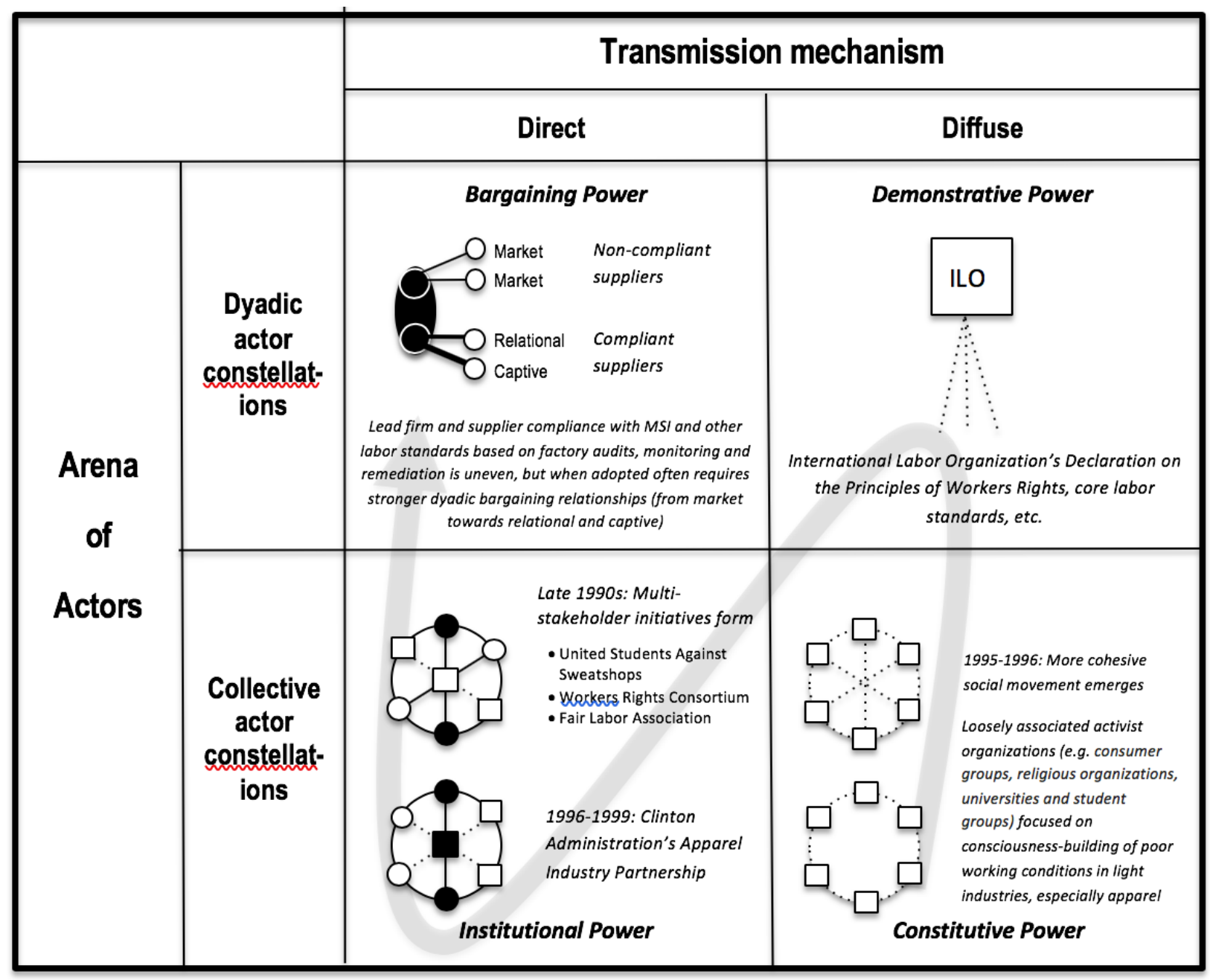


Figure 5. Illustration of power dynamics in mobile handsets: Apple iOS vs. Linux-based

\section{Google Android}

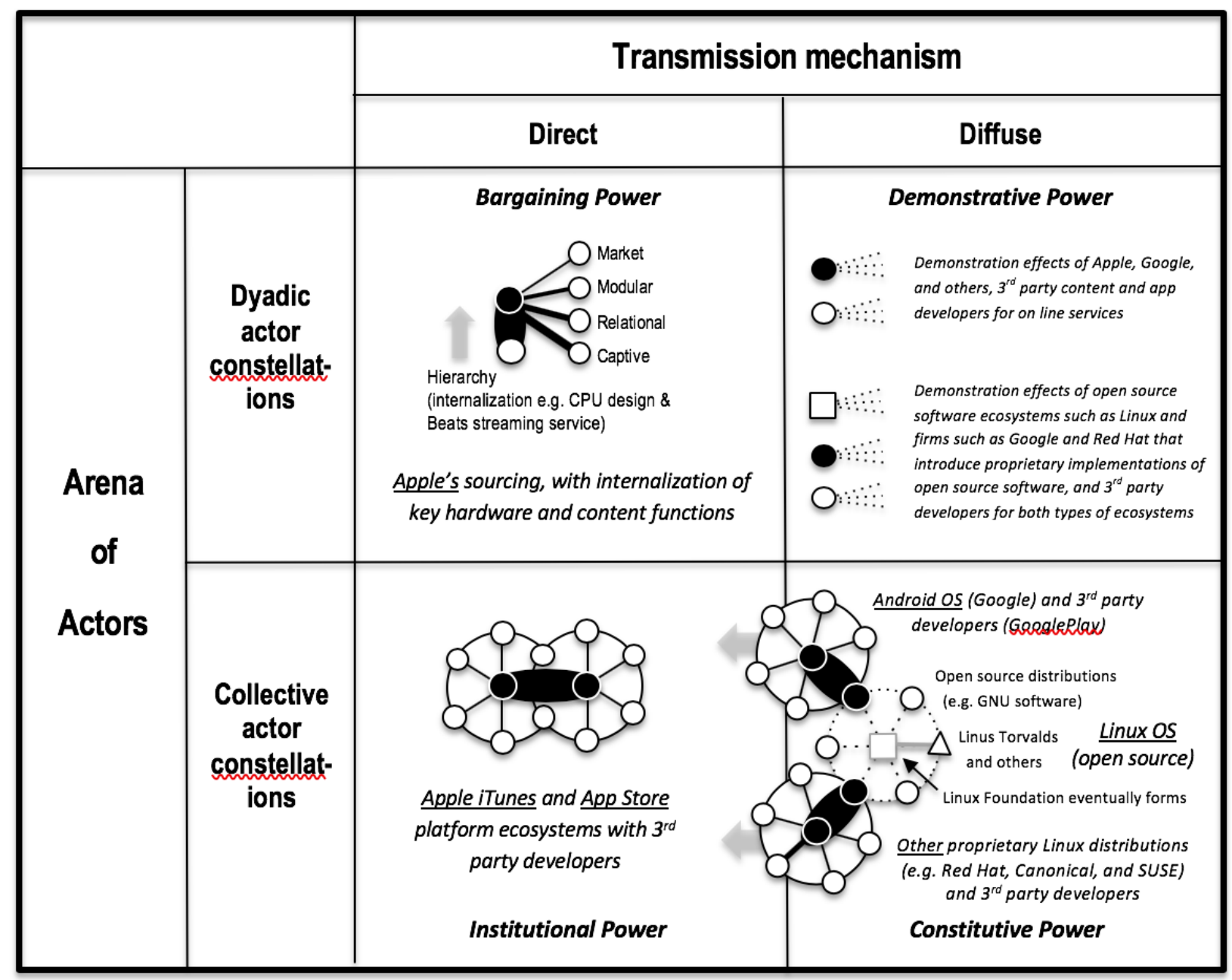

